
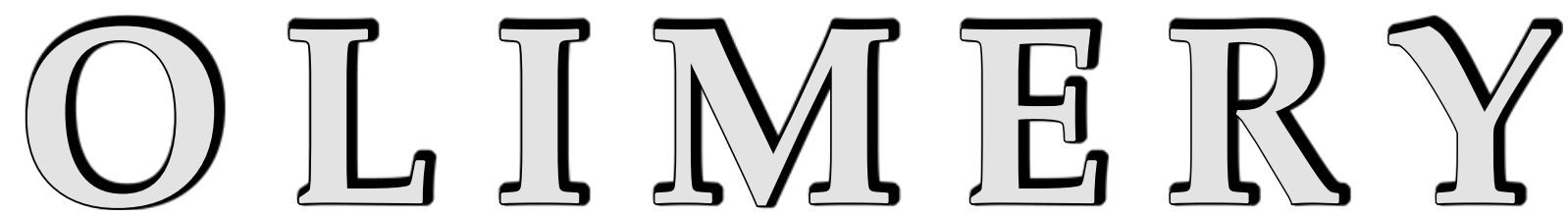

CZASOPISMO POŚWIĘCONE CHEMII, TECHNOLOGII i PRZETWÓRSTWU POLIMERÓW

\title{
Effect of nitrogen content on physical properties of glass fiber reinforced polyamide 6 prepared by microcellular injection molding
}

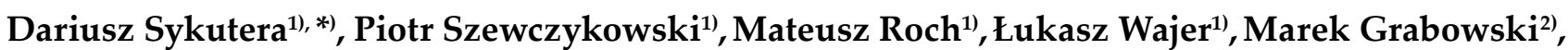 \\ Marek Bieliński ${ }^{11}$
}

DOI: dx.doi.org/10.14314/polimery.2018.11.1

\begin{abstract}
The aim of the study was to determine the effect of the amount of nitrogen dosed in supercritical state to polymer melt on structure and physical properties of large-scale molded pieces from polyamide PA6 GF30, obtained in the process of microcellular injection molding with gas dosage using MuCell $®$ method. Apart from the reduction of the density at a level of about $15 \%$ for samples with the highest nitrogen content, the increase of the impact resistance of samples PA6 GF30 was observed. The other investigated mechanical properties were maintained at a good level.
\end{abstract}

Keywords: microcellular injection molding, MuCell® technology, polyamide PA6 GF30, porous materials, mechanical properties.

\section{Właściwości fizyczne wyprasek z poliamidu 6 wzmocnionego włóknem szklanym otrzymywanych $\mathrm{w}$ procesie wtryskiwania mikroporującego w obecności azotu}

Streszczenie: Określano wpływ ilości azotu, dozowanego w stanie nadkrytycznym do stopu polimerowego, na strukturę i właściwości wielkogabarytowych wyprasek wytworzonych w procesie wtryskiwania mikroporującego metodą MuCell ${ }^{\circledR}$ z poliamidu 6 zawierającego $30 \%$ mas. krótkich włókien szklanych (PA6 GF30). Stwierdzono zmniejszenie o ok. 15 \% gęstości próbek z największą zawartością azotu oraz wzrost udarności otrzymanych wyprasek PA6 GF30, przy zachowaniu na dobrym poziomie pozostałych właściwości wytrzymałościowych.

Słowa kluczowe: wtryskiwanie mikroporujące, technologia MuCell®, poliamid PA6 GF30, materiały porowate, właściwości mechaniczne.

One of the observed trends of the development of injection molding technology is the production of light, multifunctional, large-scale molded pieces with complex geometry. Light structural composites are known, for

\footnotetext{
1) UTP University of Science and Technology, Department of Materials Engineering and Polymer Processing, Institute of Manufacturing Technology, Al. Prof. S. Kaliskiego 7, 85-796 Bydgoszcz, Poland.

2) GRAFORM Company, Wróblowa 7, 85-437 Bydgoszcz, Poland.

*) Author for correspondence; e-mail: Dariusz.Sykutera@utp.edu.pl
} 
example CFRP (carbon fiber reinforced polymer), MSP (multi-structural parts), LGF (long glass fiber), LCF (long carbon fiber) and also products of complex shapes [1-4]. An important role in these processes is played by thermoplastics, injection molding technology and especially the injection mold as a tool for the final shaping of geometrical characteristics, structure and properties of finished products. The molding tool becomes today this link in the process of producing polymer molding pieces, which integrates different technologies and provides assembly [5].

Micro- or macrocellular injection plays an important role in obtaining light and high quality injection molded parts [5-7]. The use of inert gas or chemical porophors in this process is not only a method for reducing the weight, but also gives more freedom in designing the products, especially manufactured from plastics, which are semi-crystalline. This is due to the fact that gas pores in the polymer matrix play a similar role as the holding pressure, limiting shrinkage anisotropy, deformations and internal stresses in molded pieces and also eliminate sink marks on their surface. The improvement of polymer melt viscosity and reduction or elimination of the holding pressure play important role as well [8-10].

The technology of microcellular injection molding by using inert gas is at the moment one of the most important production methods of large-size molded parts with a large surface area and small thickness. Pores obtained by $\mathrm{MuCell}{ }^{\circledR}$ technology have very small dimensions, comparing to those obtained with blowing agents. Their size ranges from 10 to $100 \mu \mathrm{m}$ and depends on the applied process parameters [8, 11-14]. Apart from the undoubted advantages of this method of modifying the structure of molded pieces, one can usually observe a decrease in mechanical strength. It is not possible to determine a clear trend in case of impact strength based on literature data, since both increase and decrease of this value can be found [15-17]. Zhenhao Xi with his team, investigated the effect of numerous variables (the amount of gas dosed, mold temperature, plasticizing temperature and injection speed) on the impact strength of polypropylene
(PP) molded pieces filled with $11.8 \mathrm{wt} \%$ glass fibers (GF) and it was indicated that this property decreases with increasing nitrogen content in the product [17].

The aim of the study was to investigate the influence of dosing the nitrogen in supercritical state on structure, geometrical characteristics and properties of large-scale molded pieces from polyamide 6 containing $30 \mathrm{wt} \%$ short glass fiber (PA6 GF30), obtained in the process of microcellular injection molding by using $\mathrm{MuCell}^{\circledR}$ technology.

\section{EXPERIMENTAL PART}

\section{Materials}

Large injection molded parts with dimensions of $680 \times 100 \mathrm{~mm}$ and about $1.9-2.1 \mathrm{~mm}$ thickness were chosen as the research objects (Fig. 1). Polyamide 6 Akulon K224-HG6 (DSM, Netherlands) was used as a material to manufacture those pieces. PA6 contained $30 \mathrm{wt} \%$ of short glass fiber (GF). Its density was $1350 \mathrm{~kg} / \mathrm{m}^{3}$, melting point temperature $220{ }^{\circ} \mathrm{C}$ and water content up to $6.3 \mathrm{wt} \%$. Material was dried in a vacuum chamber at $105^{\circ} \mathrm{C}$ for $4 \mathrm{~h}$ before being used.

\section{Specimen preparation}

Molded parts were obtained by microcellular injection molding process by use of the MuCell ${ }^{\circledR}$ technology (Trexel, USA). Pieces were produced with Engel 500 (Engel, Austria) injection molding machine at the GRAFORM company (Bydgoszcz, Poland).

The nitrogen in supercritical state was dosed at $16 \mathrm{MPa}$ pressure at four different concentrations by wt $\%: 3.2,5.5$, 8.8 and 10.0. The following injection molding process parameters were applied: filling time $1.16 \mathrm{~s}$, filling pressure 112.9 $\mathrm{MPa}$, switching point between filling-holding phase $2.5 \mathrm{~mm}$, melt temperature $285^{\circ} \mathrm{C}$, hot runner system temperature $300{ }^{\circ} \mathrm{C}$, mold temperature $50{ }^{\circ} \mathrm{C}$, holding time $0.3 \mathrm{~s}$, holding pressure $20 \mathrm{MPa}$, cooling time $28 \mathrm{~s}$. Test

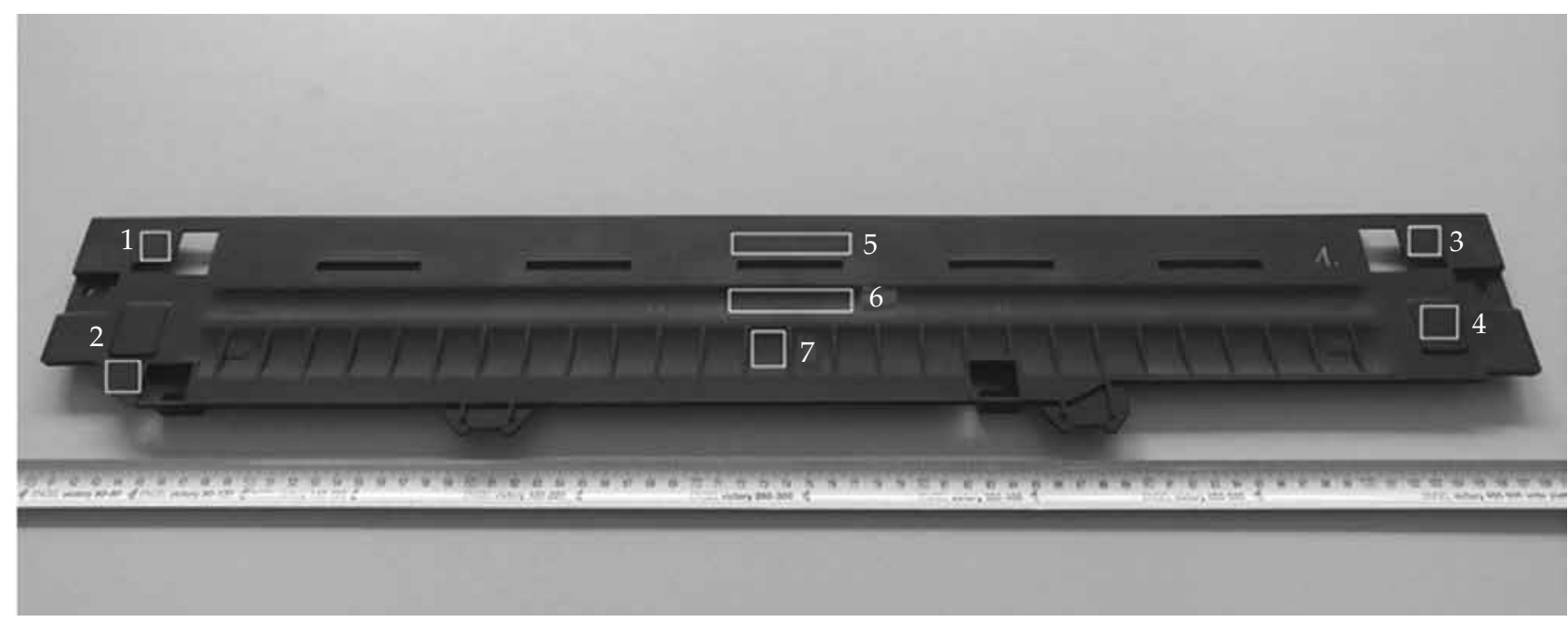

Fig. 1. Sample with marked thickness measurement points 


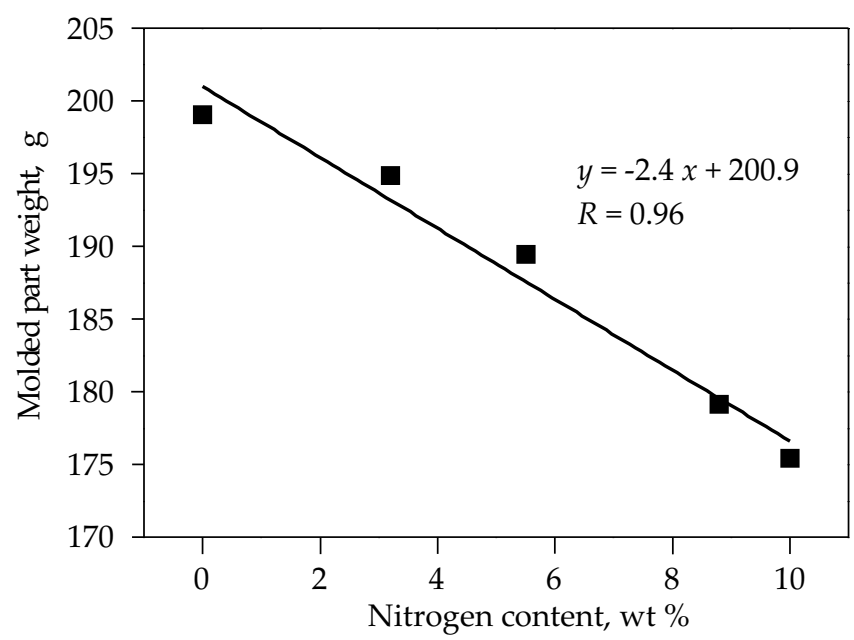

Fig. 2. Changes of microcellular PA6 GF30 molded part weight in a function of nitrogen content

specimens were cut accordingly to the ISO 527 from the obtained microcellular molded parts, with use of hydraulic press.

For the clarity of results presentation, samples were marked according to gas content as: GAS1 - $3.2 \mathrm{wt} \%$, GAS2 - $5.5 \mathrm{wt} \%$, GAS3 $-8.8 \mathrm{wt} \%$, GAS4 $-10.0 \mathrm{wt} \%$ and SOLID $-0.0 \mathrm{wt} \%$ of nitrogen gas.

\section{Methods of testing}

The effect of gas content on mechanical properties, density, deformation and pore size distribution in molded pieces was investigated.

- Mechanical properties were examined with tensile test machine Z030 (Zwick/Roell, Germany). Tensile strength (PN-EN 527) and flexural strength (PN-EN 178) were determined.

- Impact tests were realized at the temperature $23{ }^{\circ} \mathrm{C}$ and $-30{ }^{\circ} \mathrm{C}$, in accordance with PN-EN 179-1eU (Charpy impact test) by HIT50 Pendulum Impact Tester (Zwick/ Roell, Germany).

- Density was determined by hydrostatic method (methanol as immerse liquid) with use of laboratory scales AD50 (Axis, Poland).

- Warping deformation of molded parts was determined by ATOS Triple Scan 3D (GOM, Germany). Next, dimension and differences in deformation between the microcellular molded parts (GAS1) and solid samples (SOLID) were compared. A file with scanned model in STL format together with a simplified CAD model file in IGES format were imported to GOM Inspect V 7.5 software. A solid in STL was compared to CAD model. Values of deviation from scanned CAD model (in Z-direction) were determined by using software tools. Thickness of molded part was measured in seven points, marked on Fig. 1.

- Pore size and pore size distribution in molded pieces with lowest nitrogen content were determined by Bruker SkySkan 1173 computer tomography.

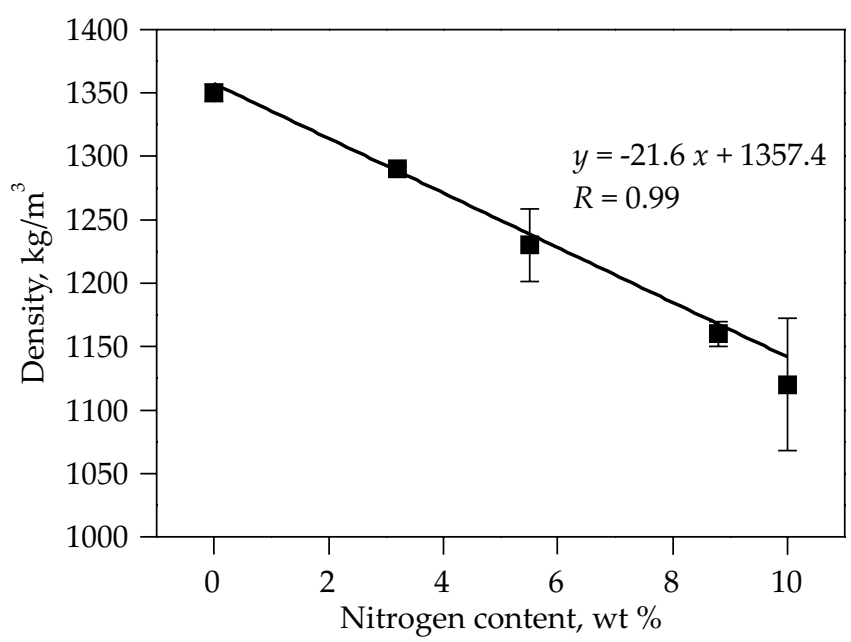

Fig. 3. Changes of microcellular PA6 GF30 molded part apparent density in a function of nitrogen content

\section{RESULTS AND DISCUSSION}

The application of nitrogen gas in supercritical state to PA6 GF30 caused significant reduction in molded pieces weight (Fig. 2).

The changes depend on the content of gas and can be described as a linear function. In case of the molded piece marked as GAS4 (nitrogen content $10 \mathrm{wt} \%$ ), the highest mass reduction was observed, which was $11.9 \%$ in relation to the SOLID sample without nitrogen gas. The range of wall thickness for all investigated samples was from 1.9 to $2.1 \mathrm{~mm}$. This means that sample mass reduction caused by nitrogen content did not influenced molded pieces dimensions, which can be considered as a positive result. It was found that the thickness of microcellular molded pieces increased from 0.02 to $0.1 \mathrm{~mm}$, in relation to the SOLID sample. These changes are noticeable already for GAS1 sample and do not depend on the amount of nitrogen introduced to polyamide matrix. The increase of thickness together with mass reduction indicates significant shrinkage minimalization and density decrease of investigated samples (Fig. 3).

Those changes can be described by linear function, similarly to the relation between samples weight and nitrogen content. The highest density reduction by about $15.0 \%$ was observed for GAS4 sample in respect to SOLID samples. Changes of weight are results of gas decompression and pores size increasing mainly in the core of molded pieces.

The above presented results correspond with geometrical cooperative analysis by 3D scanner. A significant deformation reduction of molded pieces was observed, especially in the Z-axis. This is caused by decrease of shrinkage anisotropy, commonly occurring in case of production of molded pieces with the short fibers. Such phenomenon is especially observed in case of high length elements with small thickness (about 1.5$2.5 \mathrm{~mm}$ ). Commonly, the elimination of the deformation of such molded pieces is carried out by the appropri- 
a)

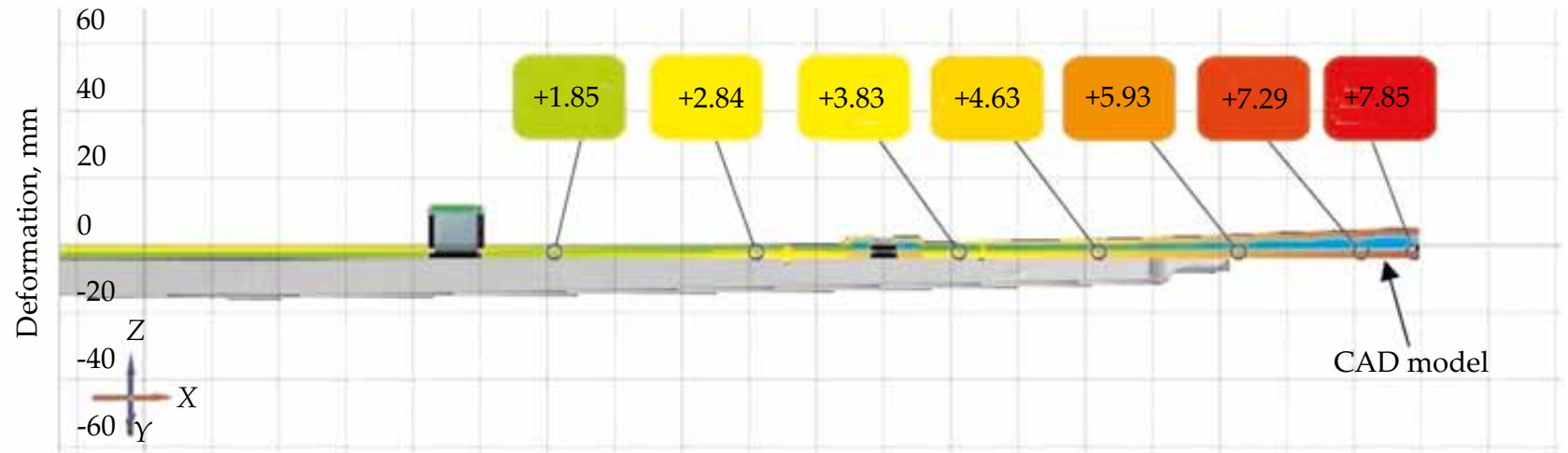

b)

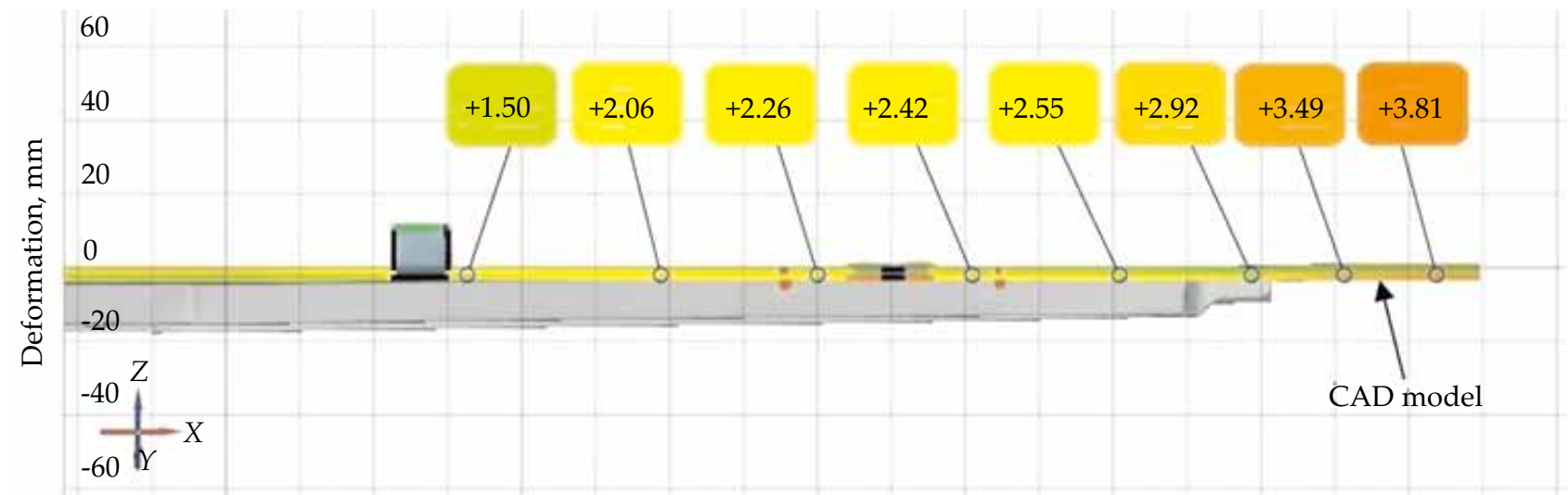

Fig. 4. Warpage analysis of molded pieces: a) SOLID sample, b) GAS1 sample; presented values show the difference in characteristic points between the real sample and the CAD model

ate mold cavity design. This process requires a lot of experience, know-how and numerous tests and corrections. Similar effect of deformation minimalization can be obtained by applying nitrogen gas (for not curved polymer flow line in the mold cavity). Comparison of deformation images of GAS1 and SOLID samples, indicate a significant deformation reduction by $4.06 \mathrm{~mm}$ in the Z-axis, just after the addition of a small quantity of nitrogen (Fig. 4).

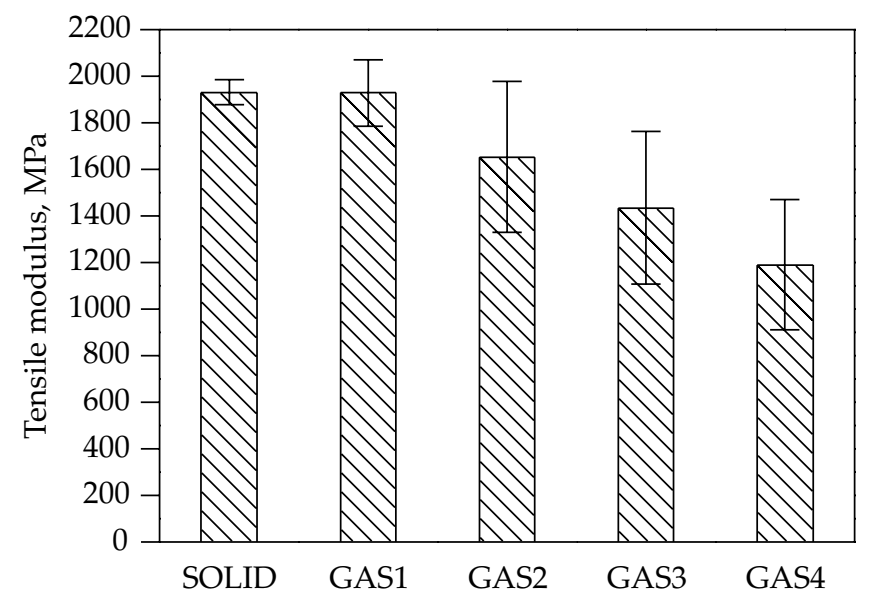

Fig. 5. Dependence of the tensile modulus of microcellular PA6 GF30 molded parts on the nitrogen content
Such changes are very difficult or impossible to obtain by changing technological parameters or the location of injection points in case of processing reinforced polymers.

Young's modulus and the tensile strength decrease with increasing the amount of gas pores in the PA6 GF30 volume (Fig. 5 and Fig. 6).

Significant decrease of tensile strength was observed for GAS2 samples. However, even in the case of molded pieces

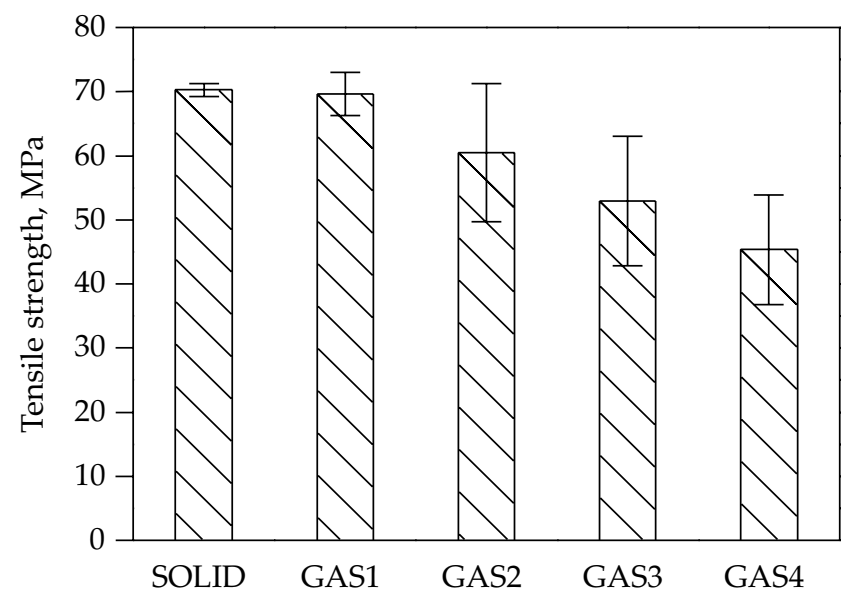

Fig. 6. Dependence of the tensile strength of microcellular PA6 GF30 molded parts on the nitrogen content 


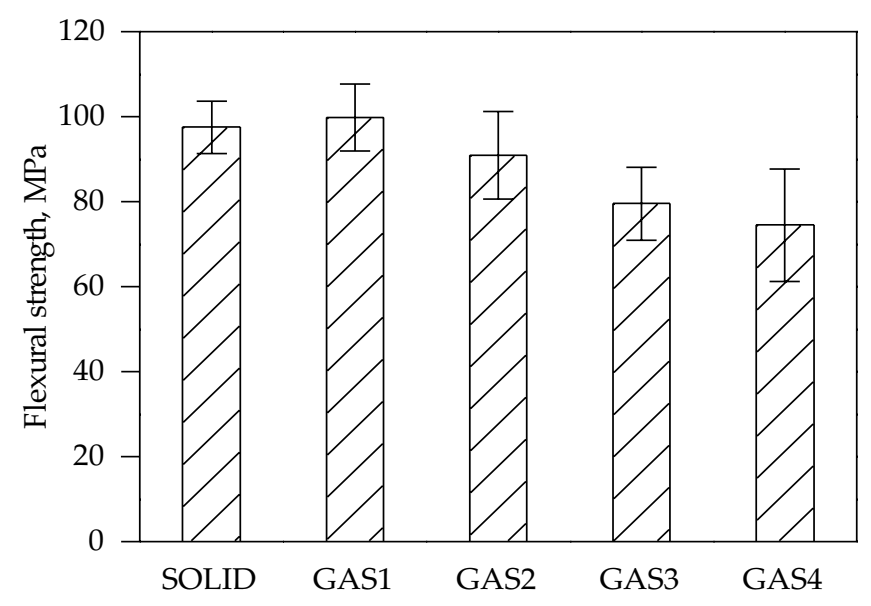

Fig. 7. Dependence of the flexural strength of microcellular PA6 GF30 molded pieces on the nitrogen content

with the highest gas content the obtained Young's modulus and tensile strength values qualify them as engineering materials. The gas pores in the polymer matrix are an additional elastic phase, which in the case of rigid polymeric materials filled with fibers can be an advantage. The elongation of modified samples increases with the amount of nitrogen, and ranges from $18.2 \pm 3.0 \%$ to $20.1 \pm 3.7 \%$ (for GAS1 and GAS4, respectively). The lowest value characterizes SOLID samples (about $16.7 \pm 3.5 \%$ ). The shape of tensile tests curves is similar for all investigated samples. Brittle fracture without noticeable yield point was observed. The effect of the content of gas in PA6 GF30 on flexural strength is similar as in case of the effect on tensile strength (Fig. 7).

The decrease of flexural strength values was observed for all molded pieces containing nitrogen gas, except for GAS1 sample. The value of this parameter is satisfactory and higher than tensile strength. That means that gas pores are not the structure weakening points during bending stress. This is confirmed by the results of Young's modulus received in the bending test. The effect of gas content in polyamide matrix on this parameter is negligible for samples GAS1 and GAS3, however an increase $(5.4 \%)$ and decrease $(13.2 \%)$ of flexural modulus was noticed for samples GAS2 and GAS4, respectively (Fig. 8).

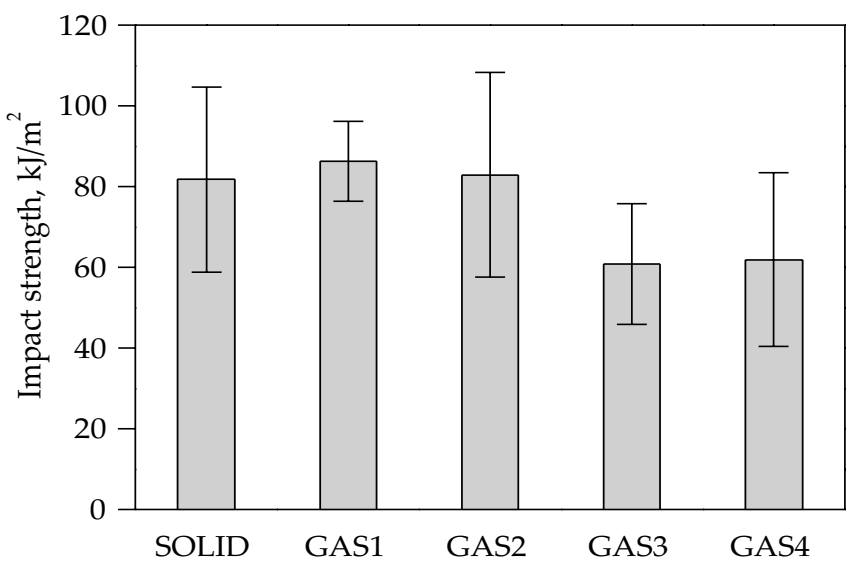

Fig. 9. Dependence of the impact strength at the $23^{\circ} \mathrm{C}$ of microcellular PA6 GF30 molded pieces on the nitrogen content

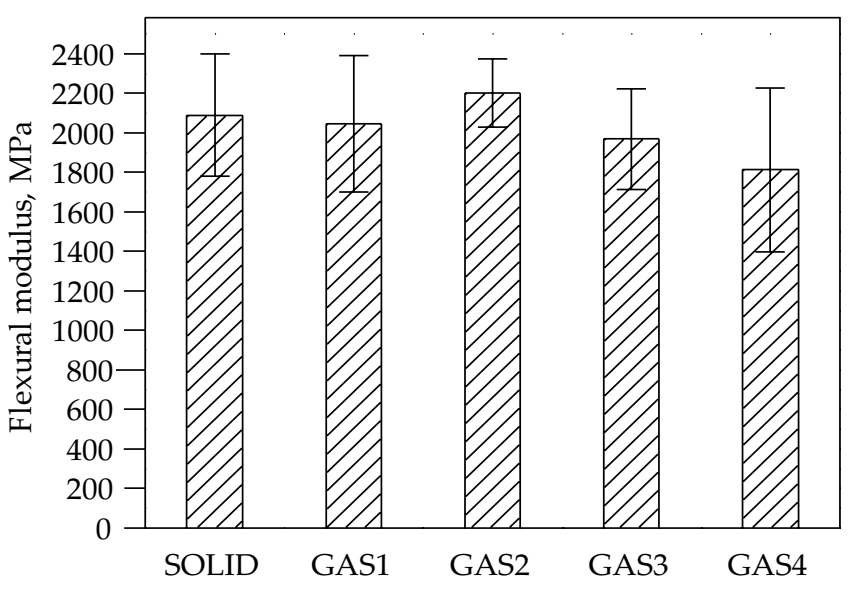

Fig. 8. Dependence of the flexural modulus of microcellular PA6 GF30 molded pieces on the nitrogen content

It should be stressed, that even though there was the highest decrease in modulus for GAS4 sample, this material is still qualified as light engineering material.

The impact tests performed in two temperatures confirm, that the micropores are additional elastic phase in polyamide matrix reinforced with short fibers. The increase in impact strength was observed for GAS1 and GAS2 samples (Fig. 9).

Further increase of gas content in molded pieces causes significant decrease of impact strength up to $50 \%$. Most probably, this is due to the fact that at high gas content an agglomeration of microcellular pores can occur, pores join each other and form macroporous areas in the PA6 matrix. This is confirmed by studies of correlation structure-strength properties described by other authors [7]. This significant reduction of both tensile and impact strength is the result of the weakening of structure cohesion by large-scale pores, which play a role of internal notches during loading. An important role of gas pores as elastic phase was confirmed by impact tests of samples frozen to $-30^{\circ} \mathrm{C}$. High values of impact strength for microporous samples were maintained, except for GAS2 sample (Fig. 10).

The high values of standard deviation occur, but it is comparable to the results of impact tests at room temper-

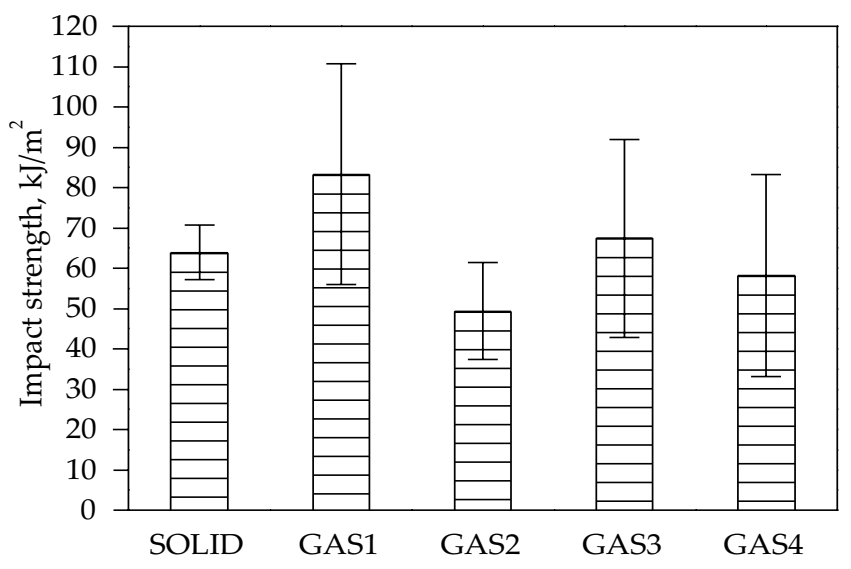

Fig. 10. Dependence of the impact strength at the $-30^{\circ} \mathrm{C}$ of microcellular PA6 GF30 molded pieces on the nitrogen content 


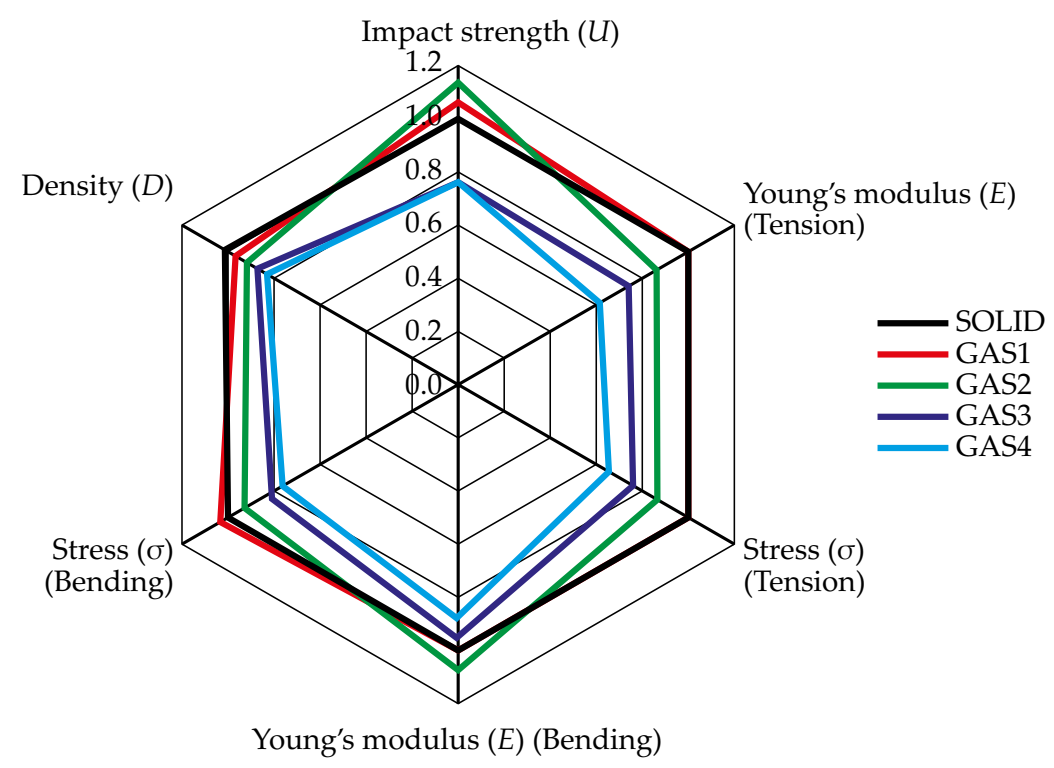

Fig. 11. A comparison of the physical properties of solid and microporous molded pieces PA6 GF30

a)

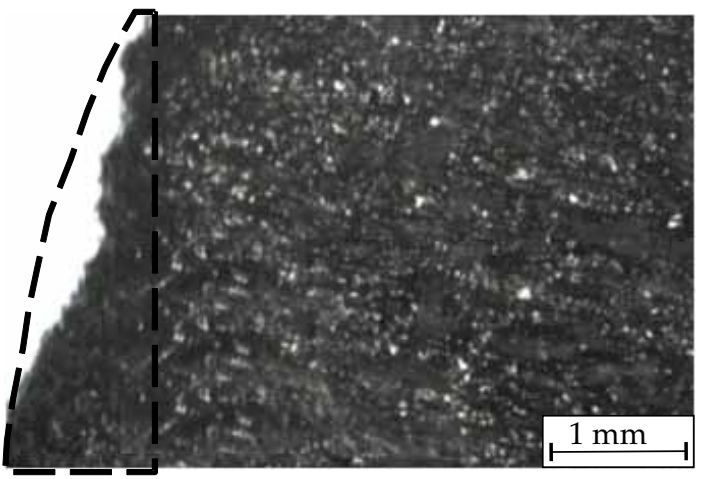

b)

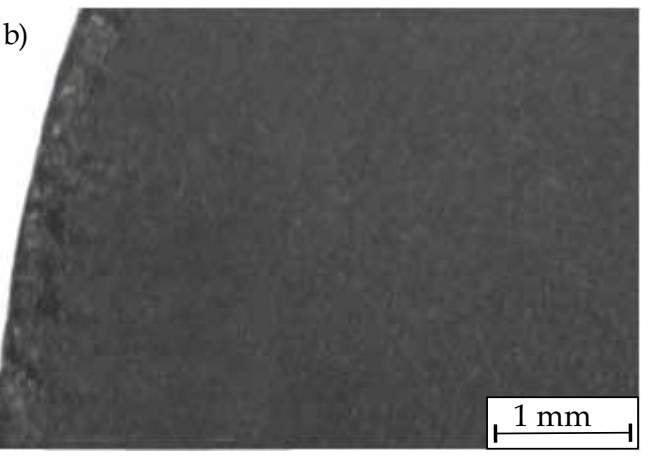

Fig. 12. A short defect for: a) highest gas content GAS4 sample comparing to b) SOLID sample without gas; short defect was observed in the upper-left sample's corner, which is in the longest distance from the injection point, a short shot area is marked by dashed line

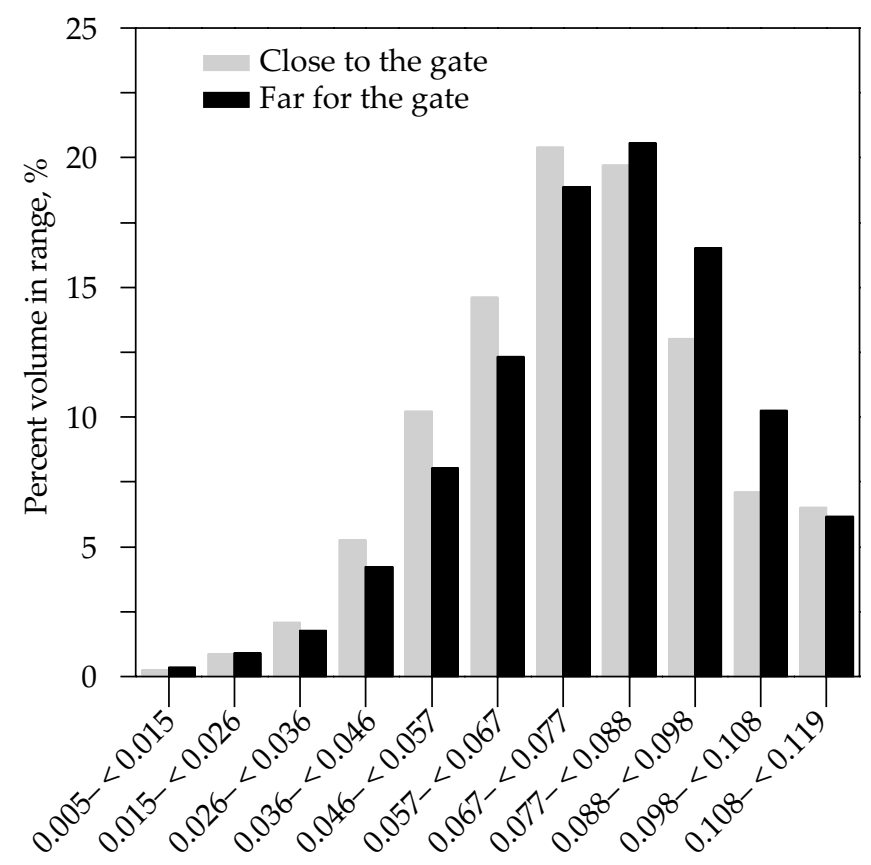

Pore size range, $\mathrm{mm}$

Fig. 13. Distribution of gas pore size in GAS1 sample ature. This is characteristic behavior for dynamic loads tests of short fibers reinforced polymers.

The obtained results are summarized in the radar diagram (Fig. 11). Even a small amount of inert gas causes decrease in density and increase in impact strength, especially at low temperatures.

One can also observe decrease in quality of molded pieces surface with increase of the nitrogen content (Fig. 12). Sink marks, micro-cracks and flow lines were observed at sample surface as the result of gas migration to the surface during mold cavity filling by polymer melt as well as during polymer flow in runners. This is an effect of shear stress at the border between polymer melt and mold or runners wall. Those defects can be removed by increasing the mold temperature during the injection phase, e.g., by induction heating, Variotherm or RHCM (rapid heat cycle molding) method [5]. Temperature influence and heat transfer phenomenon play similarly important role as those observed at pores creation in polyurethanes (PUR) [18].

Analyzing the computed tomography results it was found, that the size of gas pore in GAS1 sample ranges from 0.015 to $0.12 \mathrm{~mm}$. Pores with size of 0.057 to 


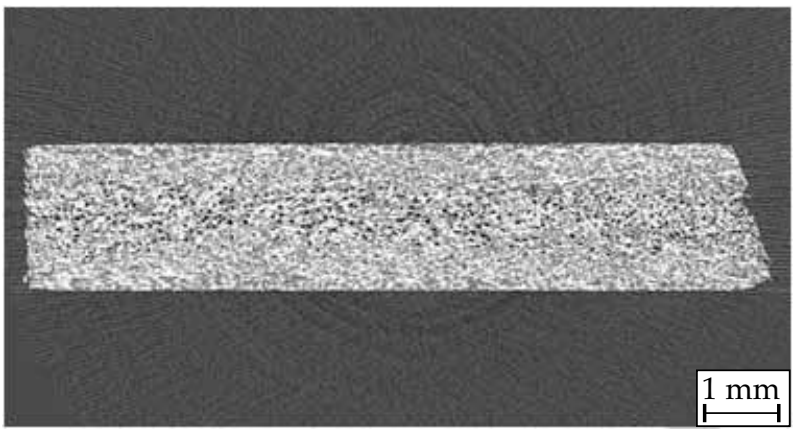

b)

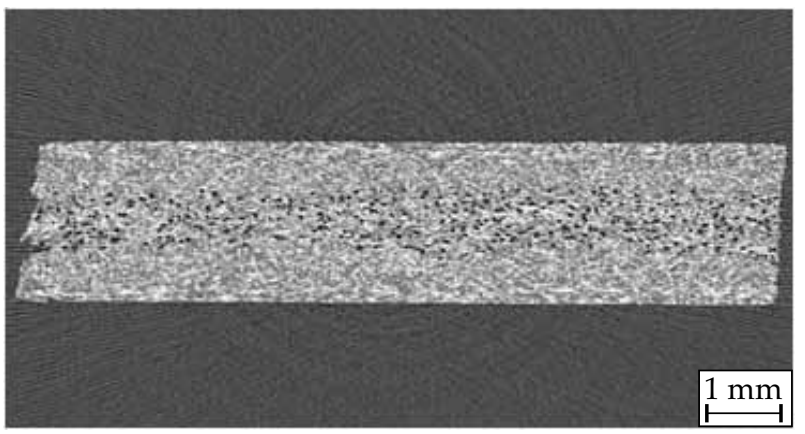

Fig. 14. Computer microtomography images of sample cross-sections with pores distribution (black spots): a) close to the gate, b) far from the gate

$0.088 \mathrm{~mm}$ dominate near the gate, which is $\mathrm{ca} .55 \%$ of total pores volume (Fig. 13). At the same time, it was found that pores in a further distance from the gate were larger, with a dominating pore size range from 0.067 to $0.098 \mathrm{~mm}$, which is again ca. $55 \%$ of total pores volume (Fig. 14). Those changes in pore size range near and far away from the gates are caused by the pressure lost on the flow length of polymer melt in the mold cavity.

\section{CONCLUSIONS}

Applying MuCell ${ }^{\circledR}$ method to modify injection molding process of PA6 GF30 caused significant (above $15 \%$ ) decrease of molded pieces density, which can be noticed as a positive effect in case of $c a .2 \mathrm{~mm}$ thickness wall elements. Even the smallest amount of nitrogen gas in a supercritical state added to the polymer melt minimized the deformation of a large-scale element by more than $50 \%$ in Z-axis. Next to the positive changes in the geometrical features and shrinkage anisotropy, decrease of tensile and flexural strength was observed. Even sample with the highest nitrogen content can still be qualified as an engineering material, since there are no significant reductions of mechanical properties. The modification of polyamide matrix with a small amount of nitrogen increases elasticity of PA6 GF30, which results in higher values of impact strength at room temperature. This feature is maintained at low $\left(-30^{\circ} \mathrm{C}\right)$ temperatures as well.

\section{REFERENCES}

[1] Troltzsch J., Helbig F., Kroll L.: Journal of Thermoplastic Composite Materials 2016, 29, 1033. https://doi.org/10.1177/0892705714554493

[2] Schuck M.: Sampe Journal 2012, 48, 20.

[3] Wu H.B., Wintermantel E.: Journal of Cellular Plastics 2010, 46, 519. https://doi.org/10.1177/0021955X10376454

[4] Kaczmar J.W., Wroblewski R., Nakonieczny L. et al.: Polimery 2008, 53, 519.

[5] Szostak M., Krzywidzińska P., Barczewski M.: Polimery 2018, 63, 145. http://dx.doi.org/10.14314/polimery.2018.2.8

[6] Chen S.C., Hsu P.S., Hwang S.S.: Journal of Applied Polymer Science 2012, 127, 4796.

http://dx.doi.org/10.1002/app.37994

[7] Bociąga E., Palutkiewicz P.: Cellular Polymers 2013, 32, 257.

[8] Palutkiewicz P., Garbacz T.: Polimery 2017, 62, 447. http://dx.doi.org/10.14314/polimery.2017.447

[9] Palutkiewicz P.: Polimery 2015, 60, 132. http://dx.doi.org/10.14314/polimery.2015.132

[10] Sykutera D., Bieliński M.: Polimery 2014, 59, 602. http://dx.doi.org/10.14314/polimery.2014.602

[11] Dong G.W., Zhao G.Q., Guan Y.J. et al.: Journal of Applied Polymer Science 2014, 131, 40365. http://dx.doi.org/10.1002/app.40365

[12] Gomez-Monterdea J., Schulteb M., Ilijevicb S. et al.: "Morphology and mechanical characterization of ABS foamed microcellular injection molding", Materials Manufacturing Engineering Society International Conference 2015, Barcelona, Spain, 2225 July 2015, pp. 15-22.

[13] Gomez-Monterde J., Sanchez-Soto M., Maspoch M.L.: Composites: Part A-Applied Science and Manufacturing 2018, 104, 1.

https://doi.org/10.1016/j.compositesa.2017.10.014

[14] Bravo V.L., Hrymak A.N.: International Polymer Processing 2005, 20, 149. https://doi.org/10.3139/217.1879

[15] Hwang S.S., Ke Z.S.: International Communications in Heat and Mass Transfer 2008, 35, 265.

https://doi.org/10.1016/j.icheatmasstransfer.2007.08.015

[16] Suhartono E., Chen S.C., Lee K.H., Wang K.J.: International Journal of Plastics Technology 2017, 21, 351. https://doi.org/10.1007/s12588-017-9190-7

[17] Xi Z.H., Sha X.Y., Liu T.: Journal of Cellular Plastics 2014, 50, 489. https://doi.org/10.1177/0021955X14528931

[18] Prociak A., Pielichowski J., Sterzynski T.: Polymer Testing 2000, 19, 705.

Received 5 II 2018. 